\title{
Characterization and distribution of pesticide use from 2015 to 2019, by health regions in the state of Rondônia (R0), Amazon, Brazil
} Caracterização e distribuição do uso de agrotóxicos no período de 2015 a 2019, por regiões de saúde em Rondônia (RO), Amazônia, Brasil

Tainara Ferrugem Franco ${ }^{1}$ (D) Renê Suaiden Parmejiani ${ }^{2}$ (), Monica Pereira Lima Cunha ${ }^{3}$ (D), Amarildo Miranda ${ }^{4}$ (D), Rejane Corrêa Marques ${ }^{1}$ (1) Jean Remy Davée Guimarães ${ }^{1}$ (1)

\section{A B S T R A C T}

Colonization projects and the consolidation of commodities production made ranching and agriculture one of the main economic activities in Rondônia (RO). Simultaneously to this process, there was an increase in the consumption of pesticides, resulting in risks to human health and the environment. Based on datasets of different origins, this article analyzed the spatial distribution of pesticide commercialization in the different health regions of the state of Rondônia (RO), between 2015 and 2019. We used data from the Rondônia State Pesticide Trade Inspection System (Sistema de Fiscalização do Comércio de Agrotóxicos do Estado de Rondônia-SIAFRO), managed by the Agrosilvopastoral Health Defense Agency of the State of Rondônia (Agência de Defesa Sanitária Agrosilvopastoril do Estado de Rondônia - IDARON); the Phytosanitary Pesticides System (Sistema de Agrotóxicos Fitossanitários - AGROFIT), the National Health Surveillance Agency (Agência Nacional de Vigilância Sanitária - ANVISA), the Brazilian Institue of the Environment and Renewable Natural Resources (Instituto Brasileiro do Meio Ambiente e dos Recursos Naturais Renováveis - IBAMA) and of the IBGE Automatic Recovery System of the Brazilian Institute of Geography and Statistics (Sistema IBGE de Recuperação Automática do Instituto Brasileiro de Geografia e EstatísticaSIDRA/IBGE). The consolidation of these data contributed to the analysis and presentation of the spatial distribution of the average amount of pesticides sold by health regions in $\mathrm{RO}$ and the main active ingredients sold, their use classification and quantity applied to each culture. We conclude that the production of commodities such as soy, corn, coffee, and pasture are the main drivers of pesticide commercialization in the study region. The main

\section{R E S U M 0}

A criação de projetos de colonização e a consolidação da produção de commodities tornou a agropecuária uma das principais atividades econômicas de Rondônia (RO). Simultaneamente a esse processo, deu-se o aumento do consumo de agrotóxicos, resultando em potenciais riscos à saúde humana e ao meio ambiente. Este artigo apresenta, com base no processamento de diversos bancos de dados, a distribuição espacial da comercialização de agrotóxicos em RO por regiões de saúde entre os anos de 2015 e 2019. Para tanto, foram utilizados dados do Sistema de Fiscalização do Comércio de Agrotóxicos de RO (SIAFRO), gerenciado pela Agência de Defesa Sanitária Agrosilvopastoril de RO (IDARON), consultas ao Sistema de Agrotóxicos Fitossanitários (AGROFIT), Agência Nacional de Vigilância Sanitária (ANVISA), Instituto Brasileiro do Meio Ambiente e dos Recursos Naturais Renováveis (IBAMA) e Sistema IBGE de Recuperação Automática do Instituto Brasileiro de Geografia e Estatística (SIDRA/IBGE). A consolidação desses dados contribuiu para a análise e a apresentação da distribuição espacial da quantidade média de agrotóxicos comercializada por regiões de saúde de RO e dos principais ingredientes ativos comercializados, classificação de uso e quantidade destinados por cultura. Concluiuse que a produção de commodities como soja, milho, café e pastagem é o principal destino dos agrotóxicos comercializados nas regiões de saúde de RO e que os principais ingredientes ativos comercializados apontam um potencial risco à saúde pública e ao

\footnotetext{
${ }^{1}$ Universidade Federal do Rio de Janeiro - Rio de Janeiro (RJ), Brazil.

${ }^{2}$ Agência de Defesa Sanitária Agrosilvopastoril do Estado de Rondônia - Porto Velho (RO), Brazil.

${ }^{3}$ Universidade Federal de Rondônia - Porto Velho (RO), Brazil.

${ }^{4}$ Fundação Osvaldo Cruz - Rio de Janeiro (RJ), Brazil.

Corresponding address: Tainara Ferrugem Franco - Av. Carlos Chagas Filho, 373, CCS, BI. G, sala 049ss - CEP: 21941-902 - Rio de Janeiro (RJ), Brazil. E-mail: tainaraff@biof.ufrj.br

Conflict of interests: the authors declare that there are no conflicts of interest.

Funding: Conselho Nacional de Desenvolvimento Cientifico e Tecnológico (CNPq) through notice MCTIC/CNPq No. 28/2018 - Universal (Process 424808/2018-8) ans scholarship (Process 141134/2019-4).
}

Received on: 12/17/2020. Accepted on: 05/20/2021

https://doi.org/10.5327/Z217694781013

This is an open access article distributed under the terms of the Creative Commons license. 
marketed active ingredients suggest potential risks to public health and the environment. In addition, the present safety criteria regarding pesticides, especially in Brazil, are outdated and lead to public health and environmental vulnerability.

Keywords: environment; environmental health; agriculture; Amazon. meio ambiente. Além disso, os padrões de segurança atuais para agrotóxicos, sobretudo no Brasil, estão desatualizados e evidenciam a vulnerabilidade ambiental e de saúde pública.

Palavras-chave: meio ambiente; saúde ambiental; agricultura; Amazônia.

\section{Introduction}

In the 1970s, the federal government started to include the state of Rondônia (RO) in the movement to expand the agricultural frontier. This process generated transformations in the territorial division of labor and in the social relationship of traditional Amazonian communities and peasants through the creation of colonization projects focused on consolidating the production of commodities, which differed according to implementation strategies and occupational dynamics (Nunes, 1996; Oliveira et al., 2014; Oliveira, 2000; Beckmann and Santana, 2019).

In order to boost agribusiness, the Development Program for the Northwest Region of Brazil (Programa de Desenvolvimento da Região Noroeste do Brasil - POLONOROESTE (1981)), financed by the World Bank, and the Agricultural and Forestry Plan of Rondônia (Plano Agropecuário e Florestal de Rondônia - PLANAFLORO (1986)) were implemented in the 1980s. These programs served as stimuli to large businesses through tax exemption, non-refundable financing, and land distribution (Pelaez et al., 2012). Shortly before, in 1975, the federal government launched the National Agricultural Defense Program (Programa Nacional de Defensivos Agrícolas - PNDA), part of the policy to modernize agriculture at the time, which subsidized credit and encouraged the establishment of the pesticide industry in the country (Agência Câmara, 2006).

As a result of these stimuli, agriculture has become one of the main economic activities in RO, being in full expansion, with a great mobilization of agribusiness aimed at the production of agricultural commodities (Beckmann and Santana, 2019; Lobão and Staduto, 2020).

This type of agricultural production is generally linked to transnational corporations and sectors of the national elite that have a specificity: the appropriation and exploitation of nature, carried out predominantly illegally, legitimizing deforestation, regularizing land appropriation, consolidating and formalizing a market dynamic and modifying economic, social and cultural structures (Beckmann and Santana, 2019; Bühler and Oliveira, 2019).

Parallel to the scenario of growth in agricultural production, there is an increase in the consumption of pesticides. As a result, the intensification of the outcomes of socio-environmental impacts is observed, which affect biological and ecosystem diversity, environmental ma- trices such as soil, surface water, air, rain, and food. In addition, this increase in pesticide consumption affects the health of rural workers and surrounding residents with irreversible damage, such as cancer, malformations, kidney and liver damage, endocrine and neurological disorders, among others (Carneiro et al., 2015; Pignati et al., 2017; Bassani et al., 2018; Lorenzatto et al., 2020).

In an attempt to make invisible the implications of environmental, human, food, and occupational exposures, which are often ignored and neglected, public institutions, researchers, health professionals, and society face difficulties in obtaining reliable information on the consumption of pesticides in Brazilian municipalities (Pignati et al., 2017; Gaboardi et al., 2019).

In some states, a database system has been implemented with the objective of monitoring and inspecting the pesticide trade, managed by state agricultural defense agencies. Following this trend, since 2011 the Agrosilvopastoral Health Defense Agency of the State of Rondonia (Agência de Defesa Sanitária Agrosilvopastoril do Estado de Rondônia IDARON) has had the Pesticide Trade Inspection System of the State of Rondônia (Sistema de Fiscalização do Comércio de Agrotóxicos do Estado de Rondônia - SIAFRO), through which companies declare the sales of these inputs (through monitoring agronomic receipts issued and controlling the packaging of the products sold).

This article proposes to present, based on the SIAFRO database, the spatial distribution of pesticide sales in the state of RO, by health regions (Rondônia, 2014), between the years 2015 and 2019. The information obtained can support the evaluation of exposure to pesticides and potential risks to human health and the environment, serving as an important source of information for future studies.

\section{Material and Methods}

The methodological construction of this article began with the collection of raw data at IDARON, the official body responsible for SIAFRO.

The data obtained via SIAFRO - after formal request - include the quantity sold and the commercial name of the pesticides, the purpose of use and the place of origin and destination by municipality in the period from 2015 to 2019. From the year 2016, the quantities of pesticides imported from other states were also obtained. Although SIAFRO has been available since 2011, its data became more consistent 
only from 2015; nonetheless, this is currently the most consolidated database in terms of quantifying pesticide use in the state of RO.

Next, the data were classified by health regions, considering units of interest for this study. The health regions are territorial sections of the Unified Health System (Sistema Único de Saúde - SUS) that bring together neighboring municipalities to gain sufficient scale and technological density to ensure comprehensive health care in at least $90 \%$ of people's needs. They are delimited based on cultural, economic, and social identities and on communication networks and shared transport infrastructure, in order to integrate the organization, planning and execution of health actions and services (Brasil, 2011; Santos, 2017). The health regions of $\mathrm{RO}$ are divided into seven territories and comprise the 52 municipalities of the state, namely: Madeira-Mamoré, Vale do Jamari, Central, Zona da Mata, Café, Cone Sul, and Vale do Guaporé (Rondônia, 2014).

The characterization of the quantity traded data was carried out considering the destination location. However, some of these locations were named by IDARON as "ignored districts" when filling out the registration in SIAFRO, on occasions when the destination location was not yet registered in the system. In these situations, for the purposes of this study, the place of origin was considered.

Based on the purpose of use data, available in the database, the percentage distributions of pesticides per crop were calculated. At SIAFRO, sales are entered in accordance with the agronomic prescription prescribed by a qualified professional with the commercial name of the pesticides. These data were used for classification of use and its active components were obtained based on the online consultation tool of the Phytosanitary Pesticides System (Sistema de Agrotóxicos Fitossanitários - AGROFIT). This system consists of a database of all pesticides and related products registered with the Ministry of Agriculture, Livestock, and Supply (Ministério da Agricultura, Pecuária e Abastecimento - MAPA), with information from the National Health Surveillance Agency (Agência Nacional de Vigilância Sanitária - ANVISA) of the Ministry of Health and information from the Brazilian Institute of Environment and Renewable Natural Resources (Instituto Brasileiro do Meio Ambiente e dos Recursos Naturais Renováveis - IBAMA) of the Ministry of Environment.

The indicators of agricultural production and economic situation Demographic Census, Agricultural Census and Municipal Agricultural Production (Produção Agrícola Municipal - PAM) - were obtained from the IBGE Automatic Recovery System of the Brazilian Institute of Geography and Statistics (Sistema IBGE de Recuperação Automática do Instituto Brasileiro de Geografia e Estatística - SIDRA/IBGE). Data from IBAMA and MAPA were obtained in the Brazilian Open Data Portal, a tool made available by the federal government since 2019 .

The formation and processing of the various databases into a single consolidated database for the analyses were carried out using Microsoft ${ }^{\circledR}$ Office Excel ${ }^{\circledR}$ software and R software, version 3.6.2. To interpret the results, descriptive analysis of the data by position and amplitude parameters was applied. The preparation and analysis of the maps was also carried out using R software, version 3.6.2.

\section{Results}

In $\mathrm{RO}$, the area of agricultural establishments accounts for $40 \%$ $(9,219,883 \mathrm{ha})$ of the total area of the state. Of these, $2.4 \%$ (223,522 ha) represent permanent crops, 5.9\% (544,793 ha) temporary crops, $88.5 \%$ $(8,159,651 \mathrm{ha})$ are destined to livestock and other animals, and $3.2 \%$ (291,917 ha) are intended for other activities in the agricultural sector, such as horticulture, floriculture, forestry, fishing, and aquaculture. In 2017, there were 91,438 agricultural establishments, and $81 \%(74,329)$ of them carried out family farming, occupying 3,480,247 hectares. Non-family establishments consisted of $19 \%(17,109)$ and occupied $5,739,636$ hectares of the total area (IBGE, 2017a).

Figure 1 shows the areas of agricultural establishments by municipality and the average planted area by municipality in the period from 2015 to 2019. The Madeira-Mamoré region comprises five municipalities, including the state capital - Porto Velho - and has a total of 1,367,638 hectares for agriculture, 1,082,228 hectares for livestock and for raising other animals, and 59,560 hectares for plantations (IBGE, 2020b).

The Central region is made up of fourteen municipalities, with $1,842,585$ hectares destined to agriculture and a planted area of 57,569 hectares. The region of Vale do Guaporé, with only three municipalities (Costa Marques, São Francisco do Guaporé and Seringueiras) has 592,773 hectares destined to agriculture, 12,905 hectares of planted area, and $98 \%(579,868 \mathrm{ha})$ of area destined to cattle raising.

The Vale do Jamari region stands out for covering the largest area destined for cattle raising in the state, with a total of $1,826,229$ hectares, while the Cone Suk region, with 349,360 hectares, has the largest planted area in the state.

The Zona da Mata region, with eight municipalities, represents $1,135,216$ hectares of agricultural establishments and has a planted area of 68,169 hectares. The Café region is made up of six municipalities, totaling 909,437 hectares for agriculture and 33,895 hectares of planted area.

According to the 2017 Agricultural Census, the state of RO is among the 15 largest consumers of pesticides in Brazil and in first place in the North region (IBGE, 2017a). In the same year, the Gross Domestic Product (GDP) of the state of RO, in current values, totaled $\mathrm{R} \$ 43$ billion ( $\mathrm{R} \$ 24,092.81$ per capita), representing $11.83 \%$ of the GDP of the North Region and $0.7 \%$ of the Brazilian GDP, mainly influenced by agriculture (Sepog, 2017).

The contribution of a given activity to the GDP is sized through the Gross Value Added (GVA), which is the final result of the productive activity in a given period. The state's total GVA grew 19.6\% in volume between the years 2016 and 2017. The agricultural GVA had a $13.5 \%$ share (BRL 5.8 billion) in the state's GDP and represented $15 \%$ of the state's total GVA (IBGE, 2017b). 

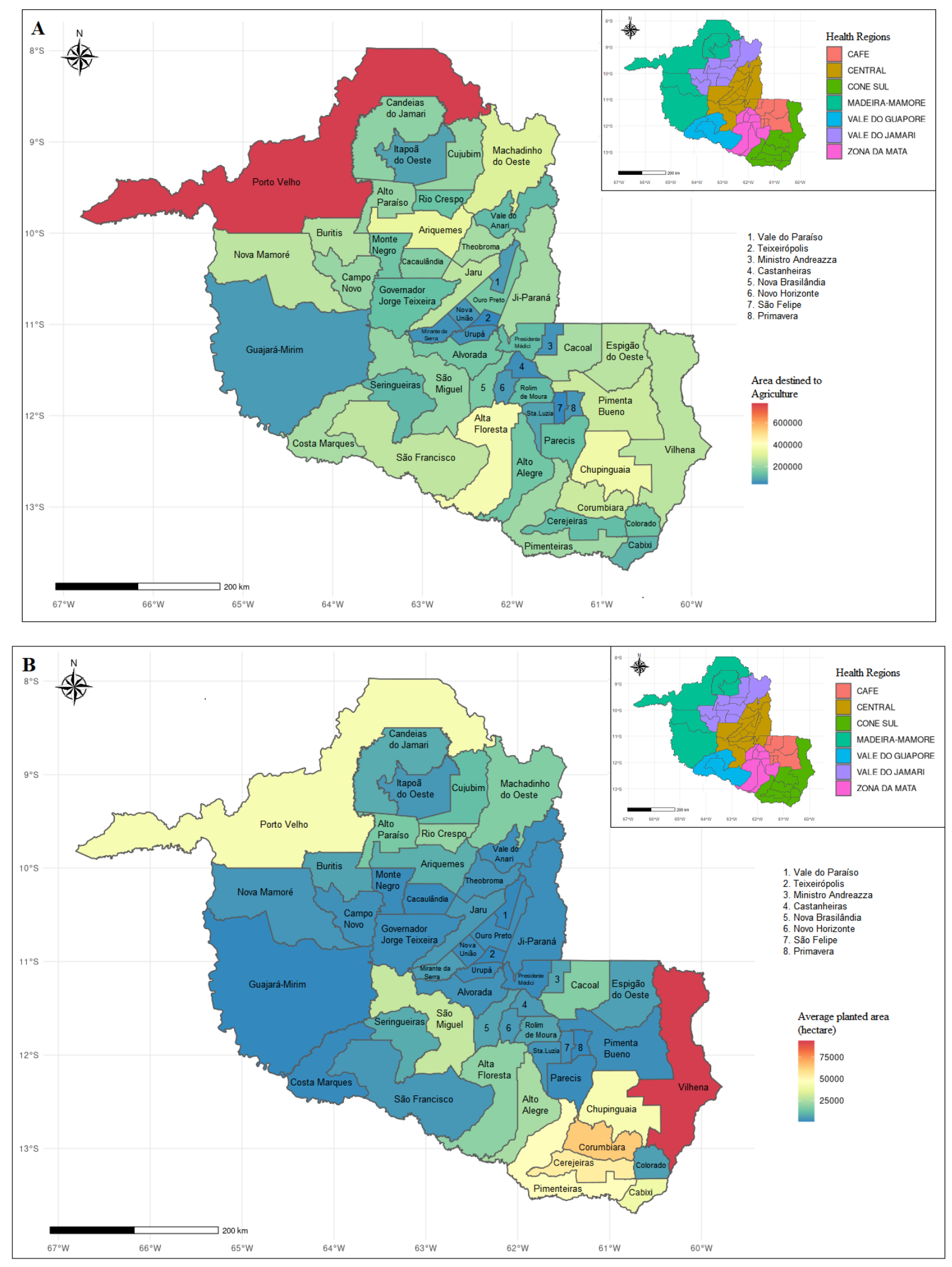

Figure 1 - Distribution of areas of agricultural establishments and average planted area (in hectares) in the municipalities of Rondônia. (A) Distribution of area destined to agriculture (in hectares) in the municipalities of Rondônia. (B) Distribution of the average planted area (in hectares) in the municipalities of Rondônia. Source: data from IBGE (2020b). 
According to the Secretary of State for Planning, Budget, and Management (Secretaria de Estado do Planejamento, Orçamento e Gestão - SEPOG), agriculture accounted for 3.3\% of the state's total GVA and the main products that contributed to the growth of the activity in volume (which was $31.6 \%$ in the year) were: soy, corn, coffee, rice, and beans. Livestock, which corresponded to $9.9 \%$ of the state's GVA, had an increase in volume of $11.1 \%$, with emphasis on milk production and the increase in the number of cattle. Forest production, fishing, and aquaculture represented 1.7\% of the state's GVA (Sepog, 2017).

Regarding the participation of municipalities in the agricultural GVA, Porto Velho stood out in relation to the others, contributing with $10 \%$ ( $\$ 589,995)$ of the state's total amount. Some municipalities concentrated more than $50 \%$ of their GDP in agriculture, namely: Corumbiara 69\%; Castanheiras 68\%; Pimenteiras do Oeste 62\%; Rio Crespo 56\%; Cacaulândia 53\%; Alto Alegre do Parecis and Governor Jorge Teixeira 52\% (IBGE, 2017b).

Between 2015 and 2017, the total amount of pesticides sold in RO registered an annual increase. In 2015, 7,231 tons of pesticides were sold, 8,961 tons in 2016 and 11,152 in 2017. A gradual reduction began in 2018, with the sale of 9,563 tons, while in 2019 there were 9,090 tons, according to data from IDARON/SIAFRO (2020).

Figure 2 shows the amount of pesticides sold in tons (average 2015-2019) in the municipalities of RO. The Cone Sul region, located in eastern Rondônia, on the border with the state of Mato Grosso, acquired a total of 17,833 tons of pesticides in the period, with an average of 3,567 tons per year, accounting for $38.8 \%$ (17,833 $t$ ) of the total acquisition of the state and standing out in relation to other regions.

The region of Vale do Guaporé, the smallest in the state, purchased a total of 1,717 tons of pesticides, with an average of 343 tons per year, the smallest amount sold among the health regions.

Figure 3 shows the amount, in kilograms per inhabitant, of pesticides sold (average 2015-2019) in the municipalities of RO. Data provided by IDARON/SIAFRO (2020) showed that between 2015 and 2019 , in terms of per capita consumption, the state had an average of 5.2 liters/inhabitant, while the national average is 8.1 liters/inhab. according to IBGE (2020a).

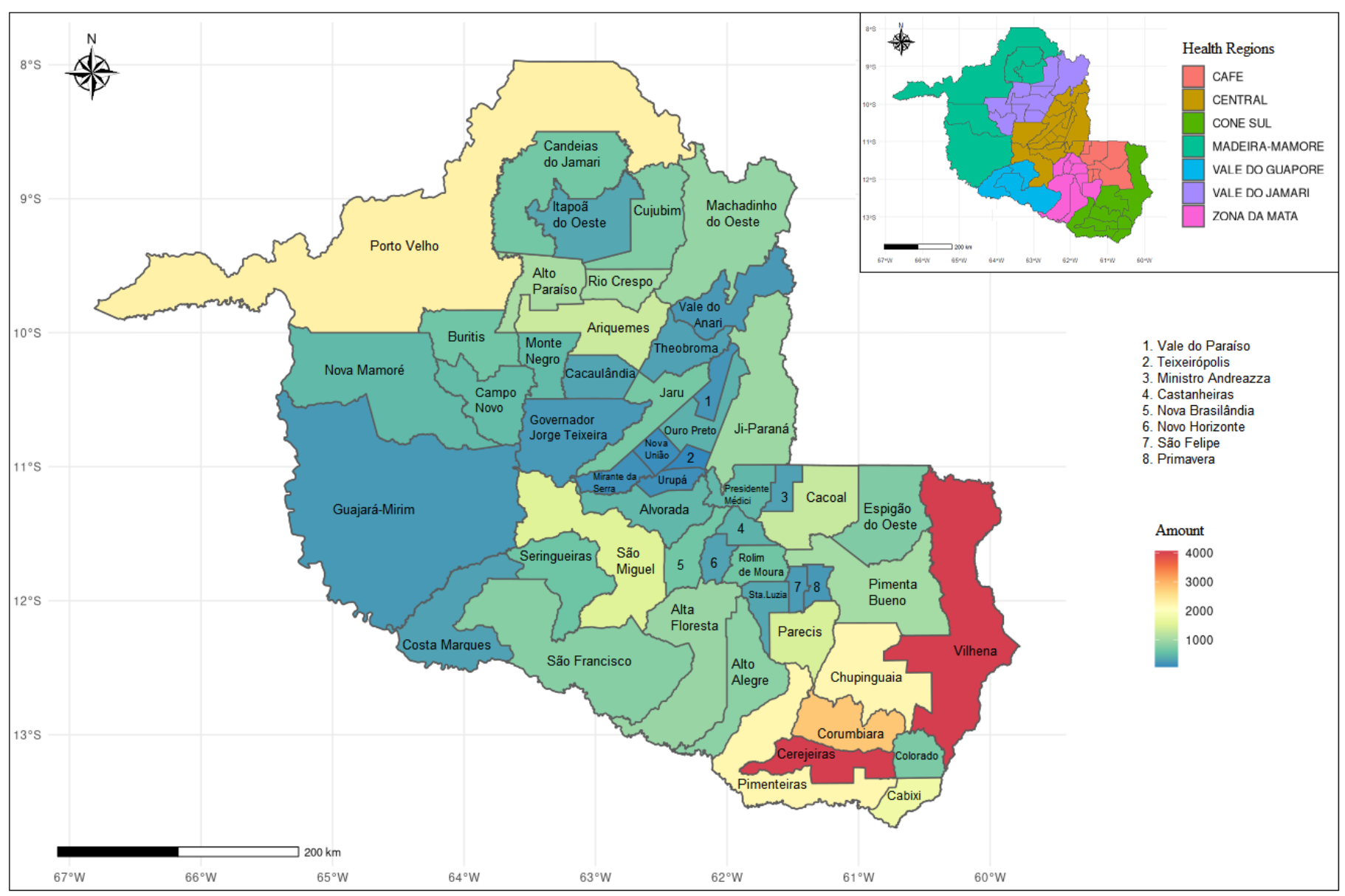

Figure 2 - Amount of pesticides sold in tons (average 2015-2019) in the municipalities of Rondônia. Source: data from IDARON/SIAFRO (2020). 
The Cone Sul region, with an average of $22.6 \mathrm{~kg} /$ inhabitant, stood out in relation to the national average and to other health regions. The municipality of Pimenteiras do Oeste, which integrates the region, had $191.34 \mathrm{~kg} /$ inhabitant, the highest amount of pesticide consumption per inhabitant, surpassing the averages of the other municipalities of $\mathrm{RO}$, the health regions, and the state and the national averages.

The Madeira Mamoré region, with an average quantity of $1.3 \mathrm{~kg} /$ inhabitant, had the lowest average among the health regions and was below the state and national averages. The municipality of Itapuã do Oeste stood out among the municipalities in the region, with an average quantity of $6.70 \mathrm{~kg} /$ inhabitant, surpassing the average for the state. However, it is important to emphasize that the region has the highest population concentration compared to other regions, a factor that contributes to the reduction in the average amount of pesticides per inhabitant.

Figure 4 shows the amount of pesticides sold (average 2015-2019) in relation to the cultivated area of temporary and permanent crops.
In Brazil, in the same period, the average amount of pesticides sold in relation to the cultivated area of temporary and permanent crops was $21.5 \mathrm{~kg}$ per hectare, with a maximum in 2019 of $23.6 \mathrm{~kg}$ per hectare (IBAMA, 2020; IBGE, 2020b).

The state of RO presented an average of $13.8 \mathrm{~kg}$ per hectare. As for the health regions, Vale do Guaporé had the highest average amount per hectare in the period $(26.7 \mathrm{~kg} / \mathrm{ha})$, the highest in $2016(30.5 \mathrm{~kg} / \mathrm{ha})$. The Cone do Sul region, with $10.2 \mathrm{~kg} / \mathrm{ha}$, the highest also in 2016 (11.9 kg/ha), had the lowest average amount of kilograms per hectare. In more than $75 \%$ (39) of the municipalities the average quantity per hectare was higher than the state average and $46 \%$ (24) of them had a higher average than that in Brazil.

In the period from 2015 to 2019 , the amount of pesticides sold was distributed as follows: $17,635 \mathrm{t}$ (38.3\%) for pasture application, 16,655 $\mathrm{t}$ (36.2\%) for soybean cultivation, 5,707 $\mathrm{t}$ (12.4\%) for corn cultivation, $2,390 \mathrm{t}$ (5.1\%) for coffee, and 3,612 t (8\%) for other crops such as beans, rice, fruits, vegetables, and others.

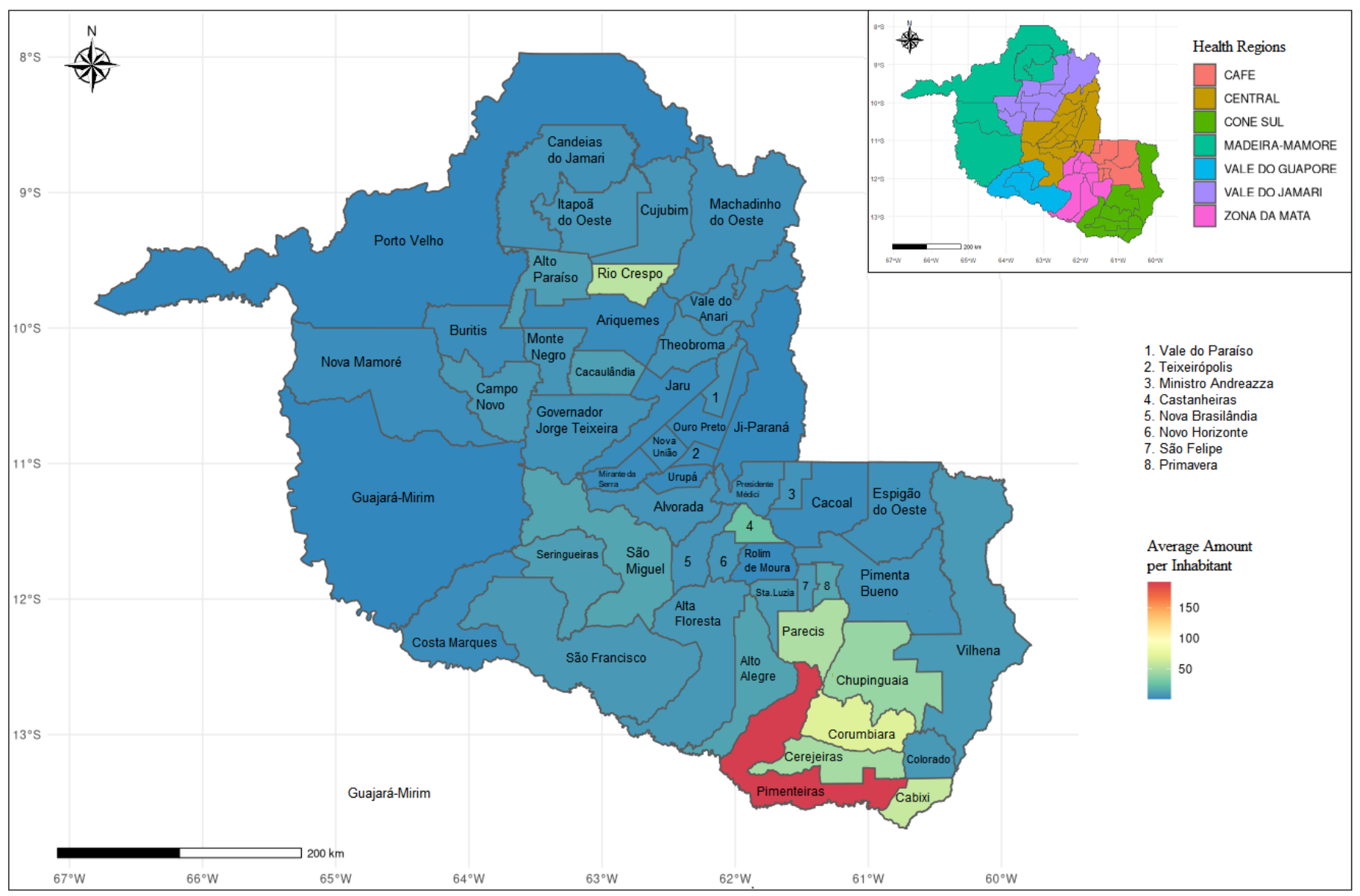

Figure 3 - Quantity in kilograms per inhabitant of pesticides sold (average 2015-2019) in the municipalities of Rondônia. Source: data from IDARON/SIAFRO (2020). 


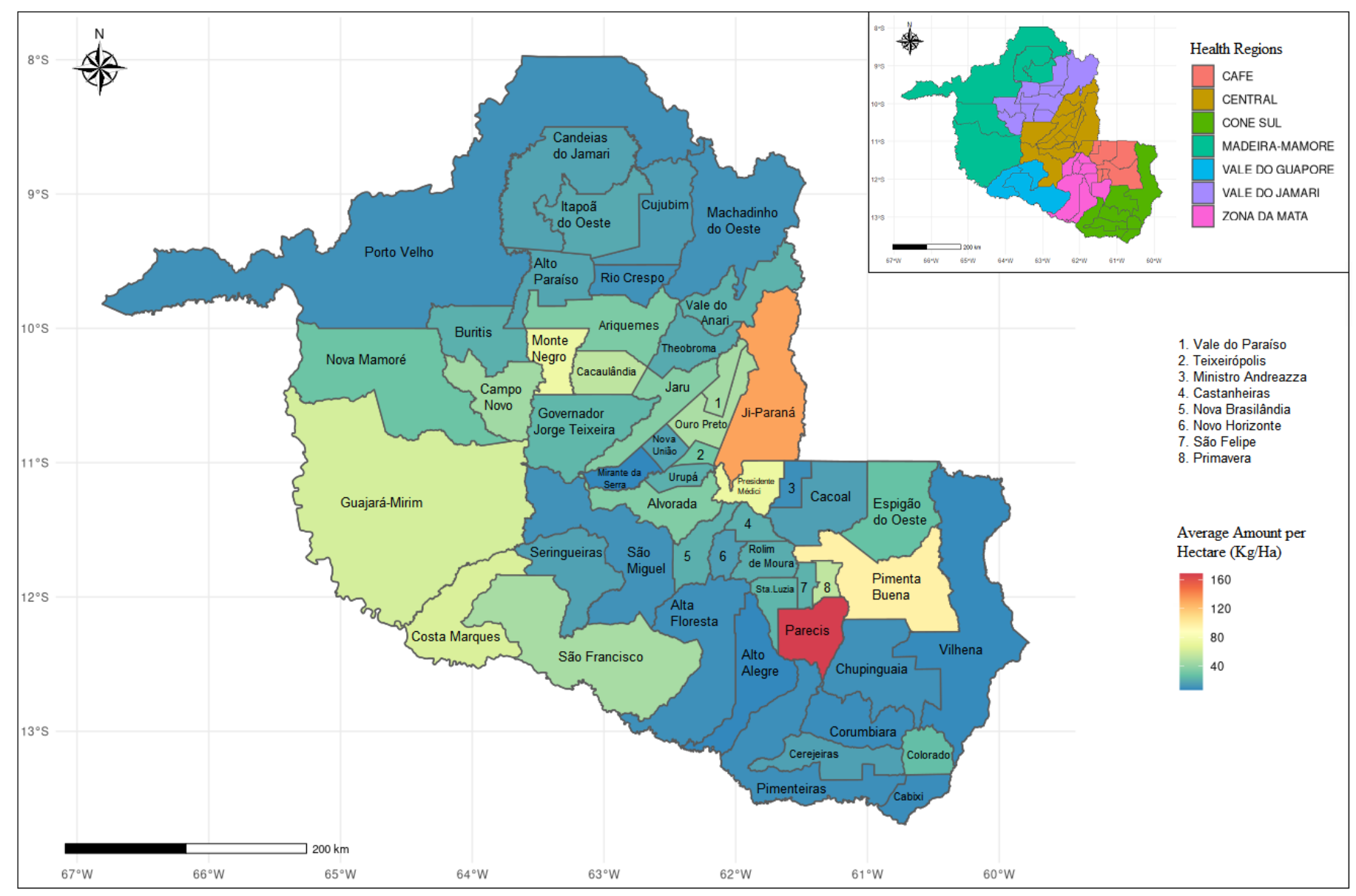

Figure 4 - Quantity of pesticides sold in kilograms per cultivated area of temporary and permanent crops (average 2015-2019) in the municipalities of Rondônia. Source: data from IDARON/SIAFRO (2020).

When the destination of pesticides sold for pasture was evaluated, the Café region had the highest percentage (69\%); the Cone do Sul the lowest percentage (10\%), and the other percentages above $48 \%$. On the other hand, when the destination was soybean cultivation, the Cone do Sul region stood out, accounting for 63\% (11,174t) of sales of these products and the Café region had the lowest percentage, $5 \%(172 \mathrm{t})$.

During this period, an average of 431 different products were sold in the state of RO. Among them, the 20 most commercialized active ingredients totaled $17,420 \mathrm{t}$, accounting for $38 \%$ of total consumption. They are: the 2,4-D herbicides, ametrine, atrazine, clomazone, diuron, flumioxazine, and glyphosate; the insecticides abamectin, acephate, fipronil, chlorpyrifos, imidacloprid, lambda-cyhalothrin, and thiamethoxam; and the fungicides azoxystrobin, carbendazim, chlorothalonil, flutriafol, mancozeb, and tebuconazole (Figure 5). In all health regions, Glyphosate is the most commercialized pesticide, except in the Café and Zona da Mata regions, where it ranks third.

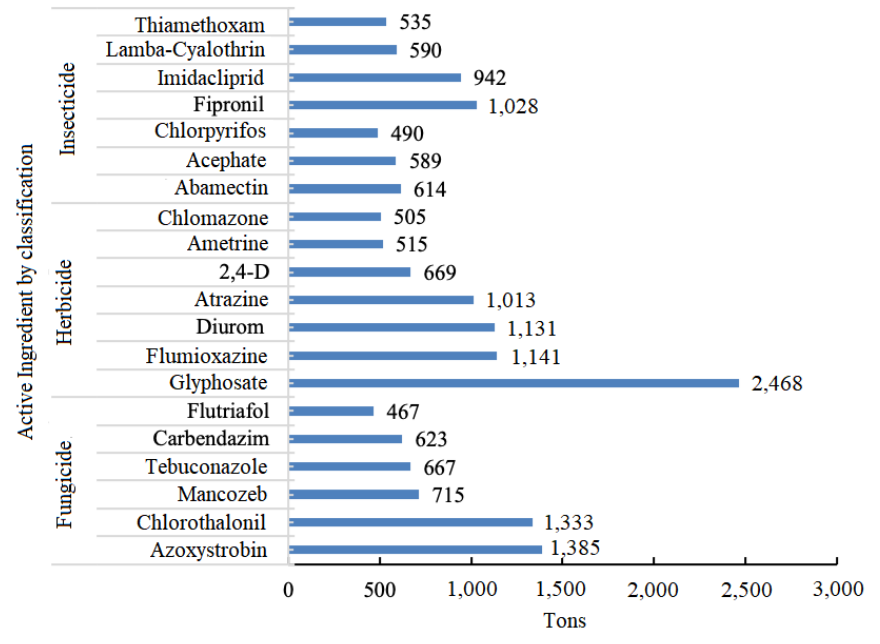

Figure 5 - Total commercialized quantity of the 20 active ingredients, by classification, in the state of Rondônia, in the period from 2015 to 2019 (in tons). Source: data from IDARON/SIAFRO (2020). 
Table 1 presents the classification of the 20 most commercialized active ingredients in $\mathrm{RO}$ regarding environmental hazard, following the following graduation:

- class I: extremely toxic;

- class II: highly toxic;

- class III: moderately toxic;

- class IV: little toxic.

And the toxicological classification:

- category 1: extremely toxic product;

- category 2: highly toxic product;

- category 3: moderately toxic product;

- category 4: little toxic product;

- category 5: product unlikely to cause acute damage;

- unclassified (Anvisa, 2019c; Brasil, 2020b).

Table 1 - Classification of environmental hazard potential and toxicological classification of the most commercialized active ingredients in the period from 2015 to 2019 in Rondônia.

\begin{tabular}{|l|l|l|}
\hline Active Ingredients & $\begin{array}{c}\text { Classification for } \\
\text { Environmental } \\
\text { Hazard }\end{array}$ & $\begin{array}{l}\text { Toxicological } \\
\text { Classification }\end{array}$ \\
\hline $2,4-\mathrm{D}$ & Class I & Category 4 \\
\hline Abamectin & Class I & Category 4 \\
\hline Acephate & Class I & Category 4 \\
\hline Ametrine & Class IV & Category 5 \\
\hline Atrazine & Class II & Category 4 \\
\hline Azoxystrobin & Class IV & Category 5 \\
\hline Carbendazim & Class III & Category 5 \\
\hline Chlomazone & Class III & Category 5 \\
\hline Chlorothalonil & Class II & Category 4 \\
\hline Chlorpyrifos & Class I & Category 3 \\
\hline Diurom & Class II & Category 5 \\
\hline Fipronil & Class I & Category 3 \\
\hline Flumioxazine & Class II & Category 5 \\
\hline Flutriafol & Class I & Category 4 \\
\hline Glyphosate & Class III & Category 5 \\
\hline Imidacloprid & Class I & Category 4 \\
\hline Lambda-Cyalothrin & Class II & Category 5 \\
\hline Thancozeb & Class I & Category 5 \\
\hline Class III & \\
\hline Class III & \\
\hline
\end{tabular}

Source: IDARON/SIAFRO (2020).

\section{Discussion}

Agribusiness has become the protagonist of economic growth in $\mathrm{RO}$, with an expressive participation in the state's economic indicators (GDP and GVA). This performance is a reflection of the expansion of agricultural frontiers over biomes, such as the Amazon forest, since the implementation of monocultures requires high productivity goals and dependence on pesticides to combat "pests" (Carneiro et al., 2012; Lobão and Staduto, 2020).

Since the implementation of monocultures, there has been a consolidation of a production model aimed at concentrating land and interfering in the way of life of traditional communities, generating an unrestrained exploitation of the environment and impacts on the health of the population (Carneiro et al., 2012; Carneiro et al., 2015; Pignati et al., 2017).

In $\mathrm{RO}$, there is land concentration concomitantly with the predominance of establishments that practice family farming. According to IBGE (2017a), the relationship between the total area devoted to agriculture (in hectares) and the number of agricultural establishments results in an average area of 47 hectares in establishments classified as family farming, while those of non-family farming reached an average of 335 hectares. This was a value higher than that found in Brazil (21 hectares in family farming and 230 hectares in non-family farming).

Since 1995, the National Program for Strengthening Family Agriculture (Programa Nacional de Fortalecimento da Agricultura Familiar - PRONAF) has been implemented, an agricultural public policy fundamental to this type of agriculture, which provides differentiated financing conditions (Bühler et al., 2016; Dyngeland et al., 2020), providing the farmer with the opportunity to expand production and/or increase productivity. On the other hand, the resources arising from this financing are largely used in the purchase of pesticides (Grisa, 2012; Bühler et al., 2016).

The use of pesticides in family farming is a challenge to both health and environment, due to the deficiency in technical assistance, the precariousness of guidelines for their proper use, the lack of perception of the risk to which these workers end up exposed, in addition to intradomiciliary contamination and inadequate disposal of waste from the production process and empty packaging of the products used (Wahlbrinck et al., 2017; Waichman et al., 2007; Buralli et al., 2018; Ndayambaje et al., 2019; Bagheri et al., 2021).

Official data for the period 2015 to 2019 show that the sale of pesticides in the state of RO decreased from the year 2018 7,231 tons were sold in 2015, 9,563 tons in 2018, and 9,090 tons in 2019 (Idaron and Siafro, 2020). For Gaboardi et al. (2019), one of the hypotheses for this reduction is the supply of illegal products, given the border between RO and Bolivia, which could favor this type of crime.

The illegal importation of these products into Brazil occurs mainly across land borders and is motivated by the fact that they are cheaper than products sold nationally (despite the fact that pesticides are ex- 
empt from taxes in Brazil), by legislation that facilitates unrestricted and free sales of products in bordering countries and by the possibility of purchasing products that are prohibited in Brazilian territory, but which are legally marketed abroad (Dorfman and Rekowsky, 2011; Lemos et al., 2018).

Other alternatives to consider for this reduction would be: the incentive to reduce the use of pesticides in $\mathrm{RO}$, in parallel with technical assistance and more adequate management techniques (however, it is not possible to obtain concrete information in this regard); and/or some type of inconsistency in the data collected in SIAFRO. Despite the broad incentive for the use and production of pesticides in Brazil, access to information about these substances is still precarious (Gaboardi et al., 2019).

The data obtained from SIAFRO are not an exact representation of the reality of pesticide consumption in RO. As in any database, several factors can introduce inconsistencies, including: purchases made without presenting the agronomic revenue, leading to an underestimation of the total traded; the use of pesticides in crops other than those indicated in the recipe, and possible typing and filling errors (Neves and Luiz, 2006).

Another example is the IBAMA data, which present information on production, import, export, and sales of active ingredients to Brazil; however, when the data is searched by states and regions of Brazil, only the quantification of sales is presented, without accounting for imports and exports, generating a lower value than the data collected in SIAFRO.

By analyzing the spatial distribution of the amount of pesticides sold in the health regions of RO (Figure 2), it was possible to relate it to the historical context of the agricultural movement in the state. An example is the Cone do Sul region, which, in 1980, had the municipality of Vilhena as a pioneer in soybean production in $\mathrm{RO}$ and later had its production spread throughout neighboring municipalities, becoming the "soy agribusiness region", with the presence of Amaggi and Cargill trading companies. There, agriculture typified as non-family predominates, increasing the importance of the region in the state's economy (Silva, 2013; IBGE, 2020b).

Until the end of the 1990s, the municipalities of Vilhena and Cerejeiras together produced practically all the soy in the state. Then, Chupinguaia and Corumbiara were also included in the production of this crop. Today, the region has the largest planted area in the state and, consequently, the largest commercialization of pesticides in relation to other health regions.

Based on the panorama of pesticide commercialization in $\mathrm{RO}$ and considering that excessive exposure to these substances causes several public and environmental health problems (Kim et al., 2017; Van Bruggen et al., 2018), one can speculate that greater chances of exposure to pesticides are in places where the ratio between the total amount of pesticides sold and the number of inhabitants is higher (Anderson et al., 2013; Dutra e Ferreira, 2017; Leão et al., 2018).
In this way, it is possible to scale the importance and assess the possible impacts of pesticides on public and environmental health. It is important to emphasize that the results do not consider that not all crops that use pesticides are for food (for example, cotton) nor do they consider the level of human exposure according to the proximity to rural areas (Gaboardi et al., 2019).

The absence of reliable control over the use of these products contributes to the invisibility of impacts, originating from their manufacturing stage, through their production chain, in addition to the risks of occupational exposure of rural producers, exposure of the population that resides or frequents nearby contaminated areas and the contamination of the environment by pesticide residues, until reaching the final consumer through the residues of these substances in food and water in urban areas (Belo and Peres, 2011; Kong et al., 2014; Mostafalou and Abdollahi, 2017; Pignati et al., 2017; FAO et al., 2018; Li et al., 2021).

Various health problems including cancer, diabetes mellitus, respiratory disorders, neurological disorders, reproductive syndromes (sexual/genital), and oxidative stress are caused by direct exposure to pesticides, handling pesticides or pesticide residues present in food (Mostafalou and Abdollahi, 2017; Chevrier and Béranger, 2018; Kalliora et al., 2018).

Certain groups of pesticides have the ability to modify the balance and function of the endocrine, immune, and neurological system (Cremonese et al., 2012; Pinheiro and Souza, 2017; de Araújo-Ramos et al., 2021). Therefore, fetal susceptibility to environmental exposure is even more critical if contact with these substances occurs early in the prenatal period, with risk of prematurity, low birth weight, reduced weight for gestational age, intrauterine growth retardation, reduced height and head circumference of the neonate, fetal death, poor Apgar score, and congenital malformations (CM), such as cryptorchidism and hypospadias (Cremonese et al., 2012; Carmichael et al., 2016; Froes Asmus et al., 2017; Ling et al., 2018; Toichuev et al., 2018). Prevention and investigation of risk factors for $\mathrm{CM}$ have been considered relevant to public health. Dutra and Ferreira (2019) analyzed the trend of CM and the use of pesticides in microregions of Brazilian states with greater production of agricultural commodities and found that the environmental exposure to pesticides suffered by the population of the studied microregions and states has increased over time, as well as the incidence of CM.

Another point to be considered is the presence of pesticide residues in water and food, which is one of the most urgent concerns in the debate on food safety in the world (FAO, 2018; Kong et al., 2014). In a study by Galvan et al. (2020) in the hydrographic basin of the São Domingos River, in Cunha Porã, Santa Catarina (SC), where the main economic activity is agriculture, it was found that $55 \%$ of the springs are contaminated with pesticides. These springs are the main sources of water to supply families, being used both "in natura" and for food preparation. 
Regarding environmental impacts, pesticides can pollute the soil, water, air, fauna, and non-target vegetation (Bhandari et al., 2020; Fernandes et al., 2020; Rani et al., 2020). Nogueira et al. (2012) found nine out of 11 active principles analyzed in surface, underground and rainwater in urban and rural areas of Lucas do Rio Verde, Mato Grosso, where the use of pesticides is considered excessive.

Also in the state of Mato Grosso, Nasrala Neto et al. (2014) recorded reports of environmental impacts caused by the use of pesticides in several municipalities, such as: contamination of the water table, mortality, and reduction of fish in rivers close to agricultural production areas, inability to produce fruits and vegetables, and vanishing of birds. In addition to these factors, the destination of use of agricultural areas is an important factor to be observed, since it introduces potential risks to human health and the environment. In RO, the use of pesticides for pasture and commodity production predominates.

The livestock production chain is identified as the main cause of deforestation, fires, and the use of pesticides, which are among the biggest environmental issues in Brazil today (Almeida et al., 2017; Mello e Artaxo, 2017; Froehlich, 2019).

The conversion of forests into pastures is carried out by clearing vegetation and burning plant material, encouraging greater use of pesticides for pasture maintenance, control of pests and herbs rejected by cattle, in addition to the use of household cleaning products in corrals and control of external and internal parasites of the herd (Focus, 2010; Pequeno and Oliveira, 2015). Another important factor is animal feed with cereals, sugar cane and other sources, in whose production pesticides are also used (Cardeal and Paes, 2006).

In Brazil, the number of pesticides authorized by the Ministries of Health and Environment and registered by MAPA is growing. In 2015, there were 139 registrations, 404 in 2017, 474 in 2019, and 405 products were registered or have already been registered in 2020 (Brazil, 2020a). Parallel to IBAMA data, eight of the 20 most commercialized active ingredients in $\mathrm{RO}$ are among the 10 most sold in Brazil in the same period (IBAMA, 2020). A key factor to be mentioned is that, of the 504 active ingredients with authorized registration, that is, allowed for use in Brazil, 149 of them are prohibited in the European Union (EU). Among the active ingredients banned in the EU, five are the most sold in RO, namely: Acephate, Atrazine, Ametrine, Abamectin, and Carbendazin (Gonçalves, 2016; Bombardi, 2017).

In Brazil, there are 150 pesticides authorized for the cultivation of soy and, of these, 35 are prohibited in the EU. For the cultivation of coffee, 121 different pesticides are authorized, 30 of which are also banned in the EU, most of them since 2002 (Bombardi, 2017).

In $\mathrm{RO}$, the most commercialized active ingredients have herbicidal action, as occurs in the rest of Brazil. Herbicides are mainly used in monocultures to avoid competition for water and nutrients with the cultivated plant, causing crop losses (Marchi et al., 2008). Among herbicides, the most commercialized active ingredient is glyphosate, which leads the ranking in RO and in Brazil, both in that period and in the last 10 years (Ibama, 2020).

In Figure 5, the quantity of glyphosate is represented only by products in which the nomenclature "glyphosate" appears. Importantly, there are several formulations that have a portion of an active ingredient, but they are of different chemical species and have different Chemical Abstract Services (CAS) registration numbers, such as: glyphosate, glyphosate potassium salt, isopropylamine salt of glyphosate, ammonium salt of glyphosate, and dimethylamine salt of glyphosate (Gaboardi et al., 2019).

In 2019, ANVISA released the new regulatory framework for pesticides (Anvisa, 2019a) in order to comply with the standards of the Globally Harmonized System of Classification and Labeling of Chemicals (GHS). This system was launched in 1992, during ECO 92, and endorsed by the General Assembly of the United Nations (UN) to strengthen international efforts related to the environmentally safe management of chemical products (Brazil, 2019). The new classification aims to match the 53 countries that adopt the GHS standards and thus strengthen the commercialization of domestic products abroad and the import of foreign products.

GHS defines the classification for product labeling purposes according to the death outcome analyzed in acute toxicological studies. The proposal is to establish scientific criteria to compare toxicity (toxic action) between products based on mortality (Anvisa, 2019b; Lopes and Padilha, 2019), which will therefore exclude all the numerous health effects that do not lead to death.

In Brazil, the registration process is carried out by three public institutions: Anvisa, which assesses issues related to human health; MAPA, which takes care of agronomic issues and is responsible for registering products for agricultural use; and IBAMA, which is responsible for environmental issues (Anvisa, 2019a).

Classifications are defined by active ingredients, without considering the inert ingredients and/or additives used in the manufacture of commercial products, nor the adjuvants used to increase their efficiency or modify certain properties of the solution. To aggravate the situation, only the active ingredients are subject to toxicological tests and not the commercial product actually used in crops.

Dutra and Ferreira (2017), when analyzing the association between the use of pesticides and congenital malformations in municipalities with greater exposure to pesticides in the state of Paraná between 1994 and 2014, cited some active ingredients that have the potential for toxic effects on the endocrine system and in the reproductive system, among which: acephate, atrazine, azoxystrobin, chlorothalonil, deltamethrin, diuron, glyphosate, and imidacloprid.

Glyphosate is a substance with potential toxic and mutagenic effects on the cardiovascular, hepatic, endocrine, and reproductive systems. It affects embryonic, fetal, and placental cells, being also recog- 
nized as an inducer of autism and depressive-like behavior (Hess e Nodari, 2018).

Atrazine, banned in the European Union since 2004 (Bombardi, 2017), has toxic properties on the immune system (Lee and Choi, 2020). In the endocrine system, it has a disruptive action on testosterone, prolactin, progesterone, luteinizing hormone, and estrogen (Zhu et al., 2021). In pregnant women, it resulted in the birth of babies with lower weight than expected, in addition to chromosomal damage in workers in atrazine-producing industries (Chevrier et al., 2011; Zhu et al., 2021).

Acephate has been banned in the EU since 2003 (Bombardi, 2017). In the analyses carried out by ANVISA's Program for the Analysis of Pesticide Residues in Food (PARA) - whose objective was to structure a service to assess and promote the quality of food that reaches the consumer in relation to the use of pesticides and the like, in the periods from 2013 to 2015 and 2017 to 2018 - Acephate had the highest rate of irregular detections, having been observed in unauthorized crops (Anvisa, 2016; 2019b).

Pesticides will continue to be part of modern agriculture and much remains to be learned about their potential exposure effects, particularly on subpopulations that may be especially sensitive. Furthermore, there are several pesticides that have been recently introduced and for which there is no data on potential toxicity.

\section{Conclusion}

The growing global demand for food intensifies concerns on food safety and the permitted levels of exposure to pesticides present throughout the production chain. In addition to the paucity of data for monitoring the marketing and use of pesticides and considering what is known to date about these substances, as well as the knowledge gaps that continue to raise concerns, it was possible to infer that current safety standards for pesticides, especially in Brazil, are outdated and may not protect public health and the environment. In this sense, this study aimed to provide a detailed overview of the marketing, destination, and use of pesticides in the state of RO. We concluded that the sale of pesticides in the state of RO decreased between 2015 and 2019. During this period, the main destinations of pesticides were application in pasture and soybean cultivation. The Café region was responsible for the highest percentage of pesticides destined for pasture, and the Cone do Sul region for soybean cultivation. The Cone do Sul region also stood out in relation to the others in the total quantity marketed and in the average per capita consumption, surpassing the national average. The main ingredients used in RO were glyphosate, chlorothalonil, azoxystrobin, diuron, flumioxazine, atrazine, and fipronil. The information generated in this work allows to identify priority areas for environmental and health monitoring in the state of Rondônia, those with greater exposure to pesticides.

\section{Author's contribution:}

Franco, T.F.: Data curation, Formal analysis, Research, Methodology, Writing - original draft and editing; Parmejiani, R.S.: Data curation, Research; Cunha, M.P.L.: Data curation, Acquisition of financing, Project administration, Resources; Miranda, A.: Data curation, Formal analysis, Methodology, Writing review; Marques, R.C.: Conceptualization, Writing - review and editing; Guimarães, J.R.D.: Conceptualization, Acquisition of Financing, Project Management, Resources, Supervision, Writing - review and editing.

\section{References}

Agência Câmara. 2006. Brasil é terceiro consumidor mundial de agrotóxico Notícias. Portal da Câmara dos Deputados (Accessed May 4, 2020) at: https:// www.camara.leg.br/noticias/89818-brasil-e-terceiro-consumidor-mundial-deagrotoxico/.

Agência de Defesa Sanitária Agrosilvopastoril do Estado de Rondônia (Idaron); Sistema de Fiscalização do Comércio de Agrotóxicos do Estado de Rondônia (Siafro). 2020. SIAFRO 2.0a. IDARON, Rondônia (Accessed May 4, 2020) at: http://www.idaron.ro.gov.br/SIAFRO/.

Agência Nacional de Vigilância Sanitária (Anvisa). 2016. Programa de análise de resíduos de agrotóxicos em alimentos para: relatório das análises de amostras monitoradas no período de 2013 a 2015. Agência Nacional de Vigilância Sanitária, Brasília.

Agência Nacional de Vigilância Sanitária (Anvisa). 2019a. Anvisa aprova novo marco regulatório para agrotóxicos. Agência Nacional de Vigilância Sanitária, Brasília (Accessed on November 19, 2019) at: http://antigo.anvisa.gov.br/.
Agência Nacional de Vigilância Sanitária (Anvisa). 2019b. Programa de Análise de Resíduos de Agrotóxicos. Relatório das amostras analisadas no período de 2017-2018. Primeiro ciclo do plano plurianual 2017-2020. Agência Nacional de Vigilância Sanitária, Brasília (Accessed on November 19, 2019) at: https://www.gov.br/anvisa/pt-br/assuntos/agrotoxicos/programa-de-analisede-residuos-em-alimentos.

Agência Nacional de Vigilância Sanitária (Anvisa). 2019c. Resolução da Diretoria Colegiada - RDC no 294, de 29 de julho de 2019. Agência Nacional de Vigilância Sanitária, Brasília (Accessed on November 19, 2019) at: http:// portal.anvisa.gov.br/agrotoxicos/reclassificacao-toxicologica.

Almeida, M.D.; Cavendish, T.A.; Bueno, P.C.; Ervilha, I.C.; Gregório, L.S.; Kanashiro, N.B.O.; Rohlfs, D.B.; Carmo, T.F.M. 2017. A flexibilização da legislação brasileira de agrotóxicos e os riscos à saúde humana: análise do Projeto de Lei no 3.200/2015. Cadernos de Saúde Pública, v. 33, (7). https://doi. org/10.1590/0102-311X00181016. 
Anderson, T.A.; Salice, C.J.; Erickson, R.A.; McMurry, S.T.; Cox, S.B.; Smith, L.M. 2013. Effects of landuse and precipitation on pesticides and water quality in playa lakes of the southern high plains. Chemosphere, v. 92, (1), 84-90. https://doi.org/10.1016/j.chemosphere.2013.02.054.

Bagheri, A.; Emami, N.; Damalas, C.A. 2021. Farmers' behavior towards safe pesticide handling: an analysis with the theory of planned behavior. Science of the Total Environment, v. 751, 141709. https://doi.org/10.1016/j. scitotenv.2020.141709.

Bassani, D.; Silva, L.R.; Birk, L.; Franco de Oliveira, S.C.W.S.E.; Dallegrave, E.; Oliveira, T.F. 2018. Pesticides in Brazil: a viewpoint about the poison law. Journal of Agricultural and Food Chemistry, v. 66, (46), 12153-12154. https:// doi.org/10.1021/acs.jafc.8b05669.

Beckmann, E.; Santana, A.C. 2019. Modernização da agricultura na nova fronteira agrícola do Brasil: Mapitoba e sudeste do Pará. Revista em Agronegócio e Meio Ambiente, v. 12, (1), 81. https://doi.org/10.17765/21769168.2019v12n1p81-102.

Belo, M.S.S.P.; Peres, F. 2011. Quando a comunicação se restringe a rotulagem: amplificando os riscos associados ao uso de agrotóxicos no meio rural brasileiro. Revista de Comunicación y Salud, v. 1, (1), 89-105. https://doi. org/10.35669/revistadecomunicacionysalud.2011.1(1).89-105

Bhandari, G.; Atreya, K.; Scheepers, P.T.J.; Geissen, V. 2020. Concentration and distribution of pesticide residues in soil: Non-dietary human health risk assessment. Chemosphere, v. 253, 126594. https://doi.org/10.1016/j. chemosphere.2020.126594.

Bombardi, L.M. 2017. Geografia do uso de agrotóxicos no Brasil e conexões com a União Europeia. FFLCH-USP, São Paulo, 296 pp.

Brasil. Ministério da Agricultura, Pecuária e Abastecimento. 2019. Anvisa vai reclassificar defensivos agrícolas que estão no mercado. Ministério da Agricultura, Pecuária e Abastecimento (Accessed on November 19, 2019) at: https://www.gov.br/agricultura/pt-br/assuntos/noti cias/anvisa-vaireclassificar-todos-os-agrotoxicos-que-estao-no-mercado.

Brasil. Ministério da Agricultura, Pecuária e Abastecimento. 2020a. Informações técnicas. Ministério da Agricultura, Pecuária e Abastecimento (Accessed on July 3, 2020) at: https://www.gov.br/agricultura/pt-br/assuntos/ insumos-agropecuarios/insumos-agricolas/agrotoxicos/informacoes-tecnicas.

Brasil. Ministério da Agricultura, Pecuária e Abastecimento. 2020b. Sistemas de agrotóxicos fitossanitários - AGROFIT. Ministério da Agricultura, Pecuária e Abastecimento (Accessed on July 3, 2020) at: http://agrofit.agricultura.gov.br/ agrofit_cons/principal_agrofit_cons.

Brasil. Ministério da Saúde. Secretaria de Gestão Estratégica. 2011. Decreto n ${ }^{\circ}$ 7.508, de 28 de junho de 2001. Regulamenta a Lei $n^{\circ} 8.080$, de 19 de setembro de 1990, para dispor sobre a organização do Sistema Único de Saúde-SUS, o planejamento da saúde, a assistência à saúde e a articulação interfederativa, e dá outras providências (Accessed on May 4, 2019) at: http://www.planalto.gov. br/ccivil_03/_ato2011-2014/2011/decreto/D7508.htm.

Bühler, E.A.; Guibert, M.; Oliveira, V.L. 2016. Agriculturas empresariais e espaços rurais na globalização: abordagens a partir da América do Sul. Editora da UFRGS. https://doi.org/10.7476/9786557250044.

Bühler, E.A.; Oliveira, V.L. 2019. A neoliberalização da natureza na fronteira agrícola do Cerrado nordestino. Raízes: Revista de Ciências Sociais e Econômicas, v. 39, (2), 262-288. https://doi.org/10.37370/raizes.2019.v39.110.

Buralli, R.J.; Ribeiro, H.; Mauad, T.; Amato-Lourenço, L.F.; Salge, J.M.; DiazQuijano, F.A.; Leão, R.S.; Marques, R.C.; Silva, D.S.; Guimarães, J.R.D. 2018. Respiratory condition of family farmers exposed to pesticides in the state of Rio de Janeiro, Brazil. International Journal of Environmental Research and Public Health, v. 15, (6), 1203. https://doi.org/10.3390/ijerph15061203.
Cardeal, Z. de L.; Paes, C.M.D. 2006. Analysis of organophosphorus pesticides in whole milk by solid phase microextraction gas chromatography method. Journal of Environmental Science and Health, Part B, v. 41, (4), 369-375. https://doi.org/10.1080/03601230600634745.

Carmichael, S.L.; Yang, W.; Roberts, E.; Kegley, S.E.; Brown, T.J.; English, P.B.; Lammer, E.J.; Shaw, G.M. 2016. Residential agricultural pesticide exposures and risks of selected birth defects among offspring in the San Joaquin Valley of California. Birth Defects Research A Clinical and Molecular Teratology, v. 106, (1), 27-35. https://doi.org/10.1002/bdra.23459.

Carneiro, F.F.; Augusto, L.G. da S.; Rigotto, R.M.; Friedrich, K.; Búrigo, A.C.; Associação Brasileira de Pós-Graduação em Saúde Coletiva. 2015. Dossiê ABRASCO: um alerta sobre os impactos dos agrotóxicos na saúde. Escola Politécnica de Saúde Joaquim Venâncio, Rio de Janeiro; Expressão Popular, São Paulo.

Carneiro, F.F.; Rigotto, R.M.; Pignati, W. 2012. Frutas, cereais e carne do Sul: agrotóxicos e conflitos ambientais no agronegócio no Brasil. e-cadernos CES, (17). https://doi.org/10.4000/eces.1101.

Chevrier, C.; Béranger, R. 2018. Pesticides and Child's Health in France. Current Environmental Health Reports, v. 5, (4), 522-530. https://doi. org/10.1007/s40572-018-0216-x.

Chevrier, C.; Limon, G.; Monfort, C.; Rouget, F.; Garlantézec, R.; Petit, C.; Durand, G.; Cordier, S. 2011. Urinary biomarkers of prenatal atrazine exposure and adverse birth outcomes in the PELAGIE birth cohort. Environmental Health Perspectives, v. 119, (7), 1034-1041. https://doi. org/10.1289/ehp.1002775.

Cremonese, C.; Freire, C.; Meyer, A.; Koifman, S. 2012. Exposição a agrotóxicos e eventos adversos na gravidez no Sul do Brasil, 1996-2000. Cadernos de Saúde Pública, v. 28, (7), 1263-1272. https://doi.org/10.1590/ S0102-311X2012000700005.

De Araújo-Ramos, A.T.; Passoni, M.T.; Romano, M.A.; Romano, R.M.; Martino-Andrade, A.J. 2021. Controversies on endocrine and reproductive effects of glyphosate and glyphosate-based herbicides: a mini-review. Frontiers in Endocrinology, v. 12, 627210. https://doi.org/10.3389/fendo.2021.627210.

Dorfman, A.; Rekowsky, C.J. 2011. Geografia do contrabando de agrotóxicos na fronteira gaúcha. Revista Geográfica de América Central, v. 2, (47E), 1-16.

Dutra, L.S.; Ferreira, A.P. 2017. Associação entre malformações congênitas e a utilização de agrotóxicos em monoculturas no Paraná, Brasil. Saúde em Debate, v. 41, (spe. 2), 241-253. https://doi.org/10.1590/0103-11042017S220.

Dutra, L.S.; Ferreira, A.P. 2019. Identificación de malformaciones congénitas asociadas a plaguicidas disruptores endocrinos en estados brasileños productores de granos, v. 18, (36). https://doi.org/10.11144/Javeriana.rgps1836.imcp.

Dyngeland, C.; Oldekop, J.A.; Evans, K.L. 2020. Assessing multidimensional sustainability: lessons from Brazil's social protection programs. Proceedings of the National Academy of Sciences of the United States of America, v. 117, (34), 20511-20519. https://doi.org/10.1073/pnas.1920998117.

Fernandes, C.L.F.; Ramires, P.F.; Moura, R.R.; Pohren, R. de S.; Volcão, L.M.; Silva Junior, F.M.R. 2020. Quais agrotóxicos estão contaminando os solos brasileiros? Research, Society and Development, v. 9, (3), e114932569. https:// doi.org/10.33448/rsd-v9i3.2569.

Focus. 2010. Pecuária bovina no Brasil: maior produtividade com menor impacto socioambiental. (Accessed on May 4, 2019) at: http://www.newsprime. com.br/abccriadores/images/upload/maior\%20produtividade $\% 20$ com $\% 20$ menor\%20impacto\%20socioambiental.pdf. 
Food and Agriculture Organization (FAO). 2018. Building climate resilience for food security and nutrition. The state of food security and nutrition in the world 2018. FAO, Roma.

Food and Agriculture Organization (FAO), United Nations International Children's Emergency Fund, World Health Organization, World Food Programme, International Fund for Agriculture Development. 2018. The state of food security and nutrition in the world 2018: building climate resilience for food security and nutrition. Food \& Agriculture Organization, Roma.

Froehlich, G. 2019. Acerca de bois sustentáveis: reflexões sobre a ambientalização a cadeia produtiva da carne. Desigualdade \& Diversidade, (17), 9-24 (Accessed on May 4, 2020) at: https://www.maxwell.vrac.puc-rio. br/46000/46000.PDF

Froes Asmus, C.I.R.; Camara, V.M.; Raggio, R.; Landrigan, P.J.; Claudio, L. 2017. Positive correlation between pesticide sales and central nervous system and cardiovascular congenital abnormalities in Brazil. International Journal of Environmental Health Research, v. 27, (5), 420-426. https://doi.org/10.1080/09 603123.2017.1373272

Gaboardi, S.C.; Candiotto, L.Z.P.; Ramos, L.M. 2019. Perfil do uso de agrotóxicos no sudoeste do Paraná (2011-2016)/Profile of pesticides use in the southwest of Paraná (2011-2016). Revista Nera, v. 22, (46), 13-40. https://doi. org/10.47946/rnera.v0i46.5566.

Galvan, K.A.; Medeiros, R.C.; Martins Neto, R.P.; Liberalesso, T.; Golombieski, J.I.; Zanella, R. 2020. Análise ambiental macroscópica e a qualidade da água de nascentes na bacia do Rio São Domingos/SC, Brasil. Revista Ibero Americana de Ciências Ambientais, v. 11, (1), 165-176. http://doi.org/10.6008/CBPC21796858.2020.001.0016

Gonçalves, M.S. 2016. Uso sustentável de pesticidas. Análise comparativa entre a União Europeia e o Brasil. Tese. Doutorado em Ciências do Ambiente, Departamento de Biologia Vegetal, Faculdade de Ciências, Universidade de Lisboa, Lisboa. (Accessed July 19, 2019) at: http://alteracoesclimaticas.ics. ulisboa.pt/wp-content/teses/2016MarciaGoncalves.pdf.

Grisa, C. 2012. Políticas públicas para a agricultura familiar no Brasil: produção e institucionalização das ideias. Tese. Doutorado em Ciências Sociais em Desenvolvimento, Agricultura e Sociedade, Programa de PósGraduação de Ciências Sociais em Desenvolvimento, Agricultura e Sociedade, Universidade Federal Rural do Rio de Janeiro, Rio de Janeiro.

Hess, S.C.; Nodari, R.O. 2018. Glifosato, o maior dos venenos. In: Hess, S.C. (Ed.), Ensaios sobre poluição e doenças no Brasil. Outras Expressões, São Paulo, pp. 151-163. (Accessed July 4, 2019) at: https://repositorio.ufsc.br/ bitstream/handle/123456789/187660/LIVRO.pdf? sequence=1\&isAllowed =y

Instituto Brasileiro de Geografia e Estatística (IBGE). 2017a. Censo agro 2017. IBGE (Accessed July 4, 2019) at: https://censoagro2017.ibge.gov.br//.

Instituto Brasileiro de Geografia e Estatística (IBGE). 2017b. Produto interno bruto - PIB. IBGE (Accessed July 4, 2019) at: https://www.ibge.gov.br/explica/pib.php.

Instituto Brasileiro de Geografia e Estatística (IBGE). 2020a. Estimativas da população residente para os municípios e para as unidades da federação brasileiros com data de referência em $1^{\circ}$ de julho de 2020. IBGE (Accessed August 4, 2019) at: https://biblioteca.ibge.gov.br/index.php/biblioteca-catalogo ?view $=$ detalhes\&id $=2101747$.

Instituto Brasileiro de Geografia e Estatística (IBGE). 2020b. PAM: produção agrícola municipal. IBGE (Accessed November 4, 2019) at: https://sidra.ibge. gov.br/pesquisa/pam/tabelas.

Instituto Brasileiro do Meio Ambiente e dos Recursos Naturais Renováveis (Ibama). 2020. Relatórios de comercialização de agrotóxicos. Ibama. (Accessed November 4, 2019) at: http://ibama.gov.br/agrotoxicos/relatorios-decomercializacao-de-agrotoxicos.
Kalliora, C.; Mamoulakis, C.; Vasilopoulos, E.; Stamatiades, G.A.; Kalafati, L.; Barouni, R.; Karakousi, T.; Abdollahi, M.; Tsatsakis, A. 2018. Association of pesticide exposure with human congenital abnormalities. Toxicology and Applied Pharmacology, 346, 58-75. https://doi.org/10.1016/j.taap.2018.03.025.

Kim, K.H.; Kabir, E.; Jahan, S.A. 2017. Exposure to pesticides and the associated human health effects. Science of the Total Environment, v. 575, 525535. https://doi.org/10.1016/j.scitotenv.2016.09.009.

Kong, W.; Ren, J.; Wang, S.; Chen, Q. 2014. Removal of heavy metals from aqueous solutions using acrylic-modified sugarcane bagasse-based adsorbents: equilibrium and kinetic studies. Bioresources, v. 9, (2), 3184-3196.

Leão, R.S.; Marques, R.C.; Buralli, R.J.; Silva, D.S.; Guimarães, J.R.D. 2018. Avaliação de saúde pública por exposição a agroquímicos. Sustentabilidade em Debate, v. 9, (1), 81-94. https://doi.org/10.18472/SustDeb.v9n1.2018.26956.

Lee, G.H.; Choi, K.C. 2020. Adverse effects of pesticides on the functions of immune system. Comparative Biochemistry and Physiology Part C: Toxicology and Pharmacology, v. 235, 108789. https://doi.org/10.1016/j.cbpc.2020.108789.

Lemos, V.F.; Carvalho, A.C.B.; Ortiz, R.S. 2018. Perfil nacional de apreensões de agrotóxicos pela Polícia Federal. Revista Brasileira de Criminalística, v. 7, (1), 21-25. https://doi.org/10.15260/rbc.v7i1.258.

Li, C.; Zhu, H.; Li, C.; Qian, H.; Yao, W.; Guo, Y. 2021. The present situation of pesticide residues in China and their removal and transformation during food processing. Food Chemistry, v. 354, 129552. https://doi.org/10.1016/j. foodchem.2021.129552.

Ling, C.; Liew, Z.; von Ehrenstein, O.S.; Heck, J.E.; Park, A.S.; Cui, X.; Cockburn, M.; Wu, J.; Ritz B. 2018. Prenatal exposure to ambient pesticides and preterm birth and term low birthweight in agricultural regions of california. Toxics, v. 6, (3), 41. https://doi.org/10.3390/toxics6030041.

Lobão, M.S.P.; Staduto, J.A.R. 2020. Modernização agrícola na Amazônia brasileira. Revista de Economia e Sociologia Rural, v. 58, (2), e188276. https:// doi.org/10.1590/1806-9479.2020.182276.

Lopes, E.V.; Padilha, N.S. 2019. Retrocessos no sistema de comunicação de riscos na rotulagem de agrotóxicos: a classificação da Anvisa. Revista de Direito Ambiental e Socioambientalismo, v. 5, (2), 55-76. http://dx.doi. org/10.26668/IndexLawJournals/2525-9628/2019.v5i2.5993

Lorenzatto, L.; da Silva, M. I.; Roman Junior, W.; Rodrigues Junior, S.; De Sá, C.; Corralo, V. 2020. Exposição de trabalhadores rurais a organofosforados e carbamatos. Brazilian Journal of Environmental Sciences (Online), v. 55, (1), 19-31. https://doi.org/10.5327/Z2176-947820200528.

Marchi, G.; Marchi, E.C.S.; Guimarães, T.G. 2008. Herbicidas: mecanismos de ação e uso. Embrapa Cerrados, Planaltina.

Mello, N.G.R. de; Artaxo, P. 2017. Evolução do plano de ação para prevenção e controle do desmatamento na Amazônia Legal. Revista do Instituto de Estudos Brasileiros, (66): 108-129. https://doi.org/10.11606/issn.2316-901x.v0i66p108-129.

Mostafalou, S.; Abdollahi, M. 2017. Pesticides: an update of human exposure and toxicity. Archives of Toxicology, v. 91, 549-599. https://doi.org/10.1007/ s00204-016-1849-x.

Nasrala Neto, E.; Lacaz, F.A. De C.; Pignati, W.A. 2014. Health surveillance and agribusiness: the impact of pesticides on health and the environment. Danger ahead! Ciência \& Saúde Coletiva, v. 19, (12), 4709-4718. https://doi. org/10.1590/1413-812320141912.03172013.

Ndayambaje, B.; Amuguni, H.; Coffin-Schmitt, J.; Sibo, N.; Ntawubizi, M; VanWormer, E. 2019. Pesticide application practices and knowledge among small-scale local rice growers and communities in Rwanda: a cross-sectional study. International Journal of Environmental Research and Public Health, v. 16, (23), 4770. https://doi.org/10.3390/ijerph16234770. 
Neves, M.C.; Luiz, A.J.B. 2006. Caracterização do Uso de Agrotóxicos. In: Embrapa Meio Ambiente (Ed.), Impacto ambiental da agricultura irrigada em Guaíra-SP. Embrapa Meio Ambiente, Jaguariúna, pp. 79-90.

Nogueira, E.N.; Dores, E.F.G.C.; Pinto, A.A.; Amorim, R.S.S.; Ribeiro, M.L.; Lourencetti, C. 2012. Currently used pesticides in water matrices in CentralWestern Brazil. Journal of the Brazilian Chemical Society, v. 23, (8), 1476-1487. https://doi.org/10.1590/S0103-50532012005000008.

Nunes, D. 1996. Rondônia: ocupação e ambiente. Boletim Presença, v. 3, (7), $39-46$.

Oliveira, O.F.; Costa, G.B.; Campos, H.A.; Silva, J.B. 2014. A implementação do plano territorial de desenvolvimento rural sustentável e do programa territórios da cidadania no estado de Rondônia. Revista Grifos, v. 20, (30-31), 81. https://doi.org/10.22295/grifos.v20i30/31.2363.

Oliveira, V.B.V. 2000. Migração e reprodução social de agricultores familiares em Nova União-Rondônia, Brasil. Tese, Programa de Pós-Graduação em Extensão Rural, Universidade Federal de Viçosa, Viçosa.

Pelaez, V.; Silva, L.; Araújo, E. 2012. Regulação de agrotóxicos: uma análise comparativa. In: $13^{\circ}$ Seminário Nacional de História da Ciência e da Tecnologia, São Paulo (Accessed May 4, 2019) at: https:// www.13snhct.sbhc.org.br/resources/anais/10/1356022660_ARQUIVO_ RegulacaoAgrotoxicosSBHC.pdf.

Pequeno, F.H.N.L.; Oliveira, A.K.F. 2015. Recuperação de pastagens como solução de impedir o desmatamento e abrir novas áreas de cultivo. Revista de Estudos Sociais, v. 17, (34), 149-152. https://periodicoscientificos.ufmt.br/ojs/ index.php/res/article/view/2596.

Pignati, W.A.; Lima, F.A.N. de S.E.; Lara, S.S. de; Correa, M.L.M.; Barbosa, J.R.; Leão, L.H. da C.; Pignatti, M.G. 2017. Distribuição espacial do uso de agrotóxicos no Brasil: uma ferramenta para a vigilância em saúde. Ciência \& Saúde Coletiva, v. 22, (10), 3281-3293. https://doi.org/10.1590/1413812320172210.17742017

Pinheiro, M.O.; Souza, C.B. 2017. Efeitos teratogênicos dos metais pesados sobre a infertilidade humana e malformações congênitas. UNILUS Ensino e Pesquisa, v. 14, (35), 47-58.

Rani, L.; Thapa, K.; Kanojia, N.; Sharma, N.; Singh, S.; Grewal, A.S.; Srivastav, A.L.; Kaushal, J. 2020. An extensive review on the consequences of chemical pesticides on human health and environment. Journal of Cleaner Production, v. 283, 124657. https://doi.org/10.1016/j.jclepro.2020.124657.
Rondônia (Estado). 2014. Resolução nº 087/CIB/RO, de 8 de maio de 2014. (Accessed May 4, 2019), at: https://www.jusbrasil.com.br/diarios/72507680/ doero-01-07-2014-pg-23.

Santos, L. 2017. Região de saúde e suas redes de atenção: modelo organizativosistêmico do SUS. Ciência \& Saúde Coletiva, v. 22, (4), 1281-1289. https://doi. org/10.1590/1413-81232017224.26392016.

Secretaria de Estado do Planejamento, Orçamento e Gestão (Sepog). 2017. Produto interno bruto - PIB dos municípios - 2017. Secretaria de Estado do Planejamento, Orçamento e Gestão, Rondônia. (Accessed July 7, 2020), at: http://www.rondonia.ro.gov.br/pib-dos-municipios-rondoniense-em-2017-foidivulgado-na-sexta-feira-13/.

Silva, R.G. da. C. 2013. Globalização, agricultura e a formação do meio técnico-científico-informacional em Rondônia. Revista ACTA Geográfica, v. 7, (15), 69-83. https://doi.org/10.5654/actageo2013.0715.0005.

Toichuev, R.M.; Zhilova, L.V.; Paizildaev, T.R., Khametova, M.S.; Rakhmatillaev, A.; Sakibaev, K.S.; Mdaykova, Z.A.; Toichueva, A.U.; Schlumpf, M.; Weber, R.; Lichtensteiger, W. 2018. Organochlorine pesticides in placenta in Kyrgyzstan and the effect on pregnancy, childbirth, and newborn health. Environmental Science and Pollution Research, v. 25, 31885-31894. https://doi. org/10.1007/s11356-017-0962-6.

Van Bruggen, A.H.C.; He, M.M.; Shin, K.; Mai, V.; Jeong, K.C.; Finckh, M.R.; Morris, J.G. Jr. 2018. Environmental and health effects of the herbicide glyphosate. Science of the Total Environment, v. 616-617, 255-268. https://doi. org/10.1016/j.scitotenv.2017.10.309.

Wahlbrinck, M.; Bica, J.; Rempel, C. 2017. Percepção dos agricultores do município de Imigrante (RS) sobre os riscos da exposição a agrotóxicos. Revista Brasileira de Ciências Ambientais (Online), n. 44, p. 72-84. https://doi. org/10.5327/Z2176-947820170128

Waichman, A.V.; Eve, E.; Nina, N.C. da S. 2007. Do farmers understand the information displayed on pesticide product labels? A key question to reduce pesticides exposure and risk of poisoning in the Brazilian Amazon. Crop Protection, v. 26, (4), 576-583. https://doi.org/10.1016/j.cropro.2006.05.011

Zhu, S.; Zhang, T.; Wang, Y.; Zhou, X.; Wang, S.; Wang, Z. 2021. Meta-analysis and experimental validation identified atrazine as a toxicant in the male reproductive system. Environmental Science and Pollution Research. https:// doi.org/10.1007/s11356-021-13396-6. 